\title{
A Case of Superior Sided Gastroschisis
}

\section{Superior Yerleşimli Bir Gastroşizis Olgusu}

\section{Ayşe KIRBAŞ, ${ }^{a}$ \\ Halil Korkut DAĞLAR, ${ }^{a}$ \\ Ebru H BIBBEROĞLU, a \\ Ali Özgür ERSOY, \\ Nuri DANIŞMANa}

${ }^{a}$ Clinic of Perinatology, Training and Research Hospital, Ankara

Geliş Tarihi/Received: 24.10 .2014 Kabul Tarihi/Accepted: 03.12.2014

This work was presented as a poster presentation at the $13^{\text {th }}$ World Congress in Fetal Medicine, June 29-July 3, 2014, Nice, France.

Yazışma Adresi/Correspondence: Ayşe KIRBAŞ

Zekai Tahir Burak Women's Health Training and Research Hospital, Clinic of Perinatology, Ankara, TÜRKIYE/TURKEY

drayse1982@yahoo.com
Zekai Tahir Burak Women's Health

\begin{abstract}
Gastroschisis is a full-thickness congenital defect in the abdominal wall characterized by protruding abdominal organs without an overlying sac occurs in about 1 in 5-10,000 live births. An increase in incidence has been reported worldwide over recent years. The etiology of the defect is unknown. It nearly always located to the right of the umbilicus; left-sided gastroschisis is extremely rare. Herein, we present an unusual case of gastroschisis in which the defect was on the superior side of the umbilical cord. Although gastroschisis generally is considered a fetal anomaly that can be completely cured postnatally, the fetal health course was troublesome in our case. Defining and reporting these extraordinary cases is essential to further expand our understanding of these pathologies and their potential associations.
\end{abstract}

Key Words: Prenatal diagnosis; abdominal wall; gastroschisis

ÖZET Gastroşizis, abdominal organların, abdominal duvarın tüm katlarını içeren konjenital bir defektten, üzerlerini örten bir kese olmaksızın batın dışına protrüzyonuyla karakterizedir. 5-10.000 canlı doğumdan 1'inde görülür. Son yıllarda dünya genelinde gastroşizisin görülme sıklığında bir artış bildirilmiştir. Defektin etiyolojisi hala net olarak bilinmemektedir. Defekt hemen daima umbilikusun sağ tarafında yer alırken, defektin solda olması oldukça nadirdir. Burada, daha önce literatürde bildirilmemiş, umbilikal kordun üstünde yerleşmiş bir defektten kaynaklanan sıradışı bir gastroşizis olgusu sunulmaktadır. Gastroşizis genellikle postnatal dönemde tamamen tedavi edilebilen bir fetal anomali olarak bildirilse de, bizim olgumuzda fetal prognoz oldukça kötü seyretti. Olağandışı olguların tanımlanması ve raporlanması, bu patolojileri ve potansiyel bağlantılarını anlamamız açısından oldukça onemlidir.

Anahtar Kelimeler: Prenatal tanı; karın duvarı; gastroşizis

Turkiye Klinikleri J Gynecol Obst 2015;25(4):271-4

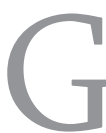
astroschisis (Greek for "belly cleft") is a full-thickness defect in the abdominal wall characterized by protruding abdominal organs without an overlying sac. ${ }^{1}$ The reported incidence of gastroschisis is 1 in 5-10 000 live births and it is associated with young maternal age, smoking and exposure to certain drugs (such as methamphetamines and salicylates). ${ }^{2,3}$

Gastroschisisis nearly always located to the right of the umbilicus; leftdoi: 10.5336/gynobstet.2014-42189 sided gastroschisis is extremely rare and is associated with a higher incidence of extraintestinal anomalies. ${ }^{4}$ Only one case of inferior gastroschisis 
has been reported in the literature, and superior gastroschisis has never been reported. ${ }^{5}$ Herein, we present a case of gastroschisis in which the defect was on the superior side of the umbilical cord.

\section{CASE REPORT}

A 22-year-old primigravida was referred to our perinatology clinic at 18 weeks of gestation due to abnormally high maternal alpha fetoprotein AFP levels in triple tests. A detailed ultrasound scan revealed an echogenic mass protruding from the anterior abdominal wall, which was diagnosed as gastroschisis. No other anomalies were detected on the ultrasound scan.

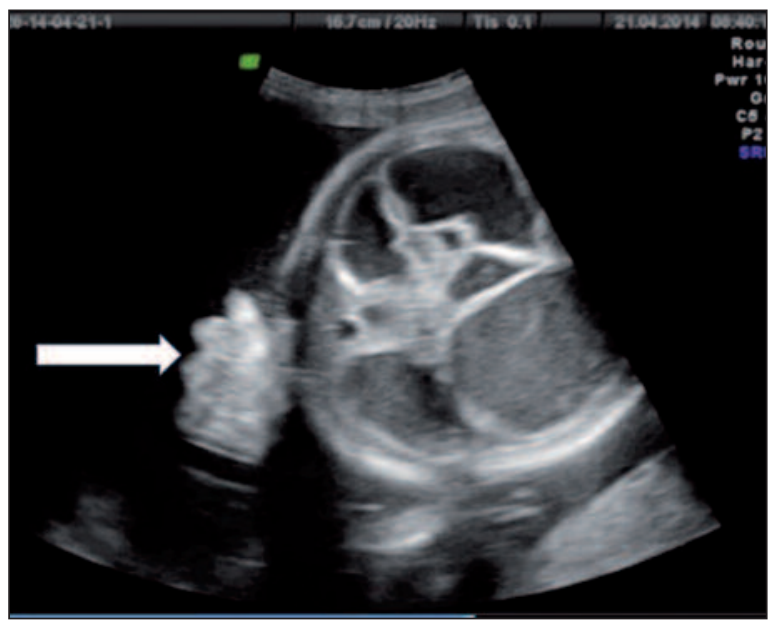

FIGURE 1: Massive intraabdominal bowel dilatation in the case of gastrochsisis at $32^{\text {th }}$ weeks' gestation. White arrow: free-floating loops of intestine in the amniotic fluid.
Serial ultrasound examinations performed at 21,26 , and 30 weeks of gestation only showed free loops of collapsed bowel and minimal hydramnios. At 32 weeks of gestation, dilated intra-abdominal bowels that had not been seen on any previous scan were visualized on ultrasound (Figure 1); the transverse diameter of the bowel was measured at 27 $\mathrm{mm}$. Interestingly, we noted that the bowel dilatation disappeared the following week but reappeared at 34 weeks, only to disappear again at 35 weeks.

The baby was delivered by caesarean section for fetal distress at 38 weeks of gestation, weighing 2850 grams and with APGAR scores of 7 and 9.

The eviscerated bowel loops were not covered by membrane (Figure 2A and B). Surgery was performed the same day; the findings were an abdominal wall defect superior to the umbilicus and intestinal (ileal and jejunal) atresias. Primary closure of the defect and three ileostomies were performed after resection of $18 \mathrm{~cm}$ of bowel.

Necrotizing enterocolitis, short bowel syndrome, intestinal failure, and sepsis complicated the infant's postoperative course, and he died of severe sepsis on his 187th day life after an intestinal transplantation.

Informed consent was obtained from the patient for publication of this case report and any accompanying images.
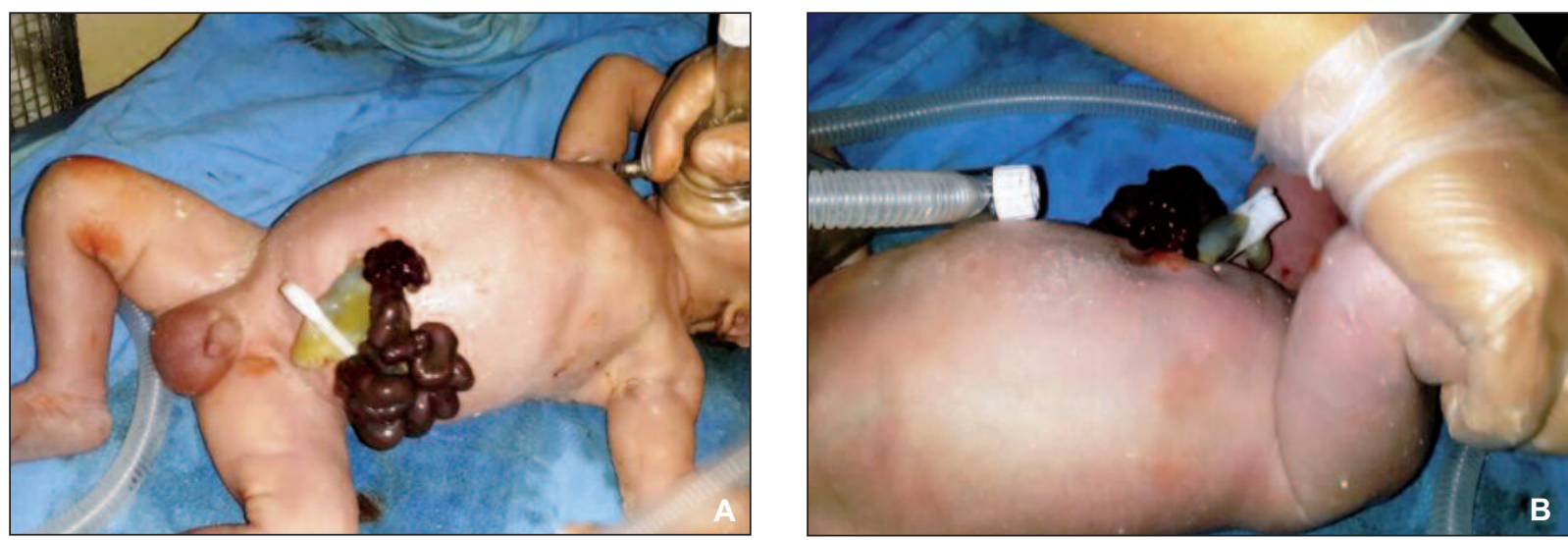

FIGURE 2: Superior sided gastroschisis at birth. 


\section{DISCUSSION}

To the best of our knowledge, this is the first case of superior-sided gastroschisis reported in the literature.

The most of gastroschisis cases are diagnosed prenatally due to using of routine maternal serum screening tests and fetal ultrasonography. As second trimester maternal serum-alpha-fetoprotein (MSAFP) screening has become incorporated into antenatal care, more cases of gastroschisis are being detected in utero. ${ }^{6}$ Cauliflower-like intestinal loops floating freely in the amniotic fluid is the characteristic ultrasonographic finding of gastroschisis. Evisceration of the other abdominal organs is seen rarely. ${ }^{1,2}$

While the exact etiopathogenesis of gastroschisis is still uncertain, it has been argued that a vascular compromise within the embryonic period may be responsible for the development of the abdominal wall defect. ${ }^{7}$

Inadequate obliteration of the right umbilical vein or of the right omphalomesenteric artery could lead to either weakness or necrosis of the forming abdominal wall..$^{8,9}$ It is very interesting to note that left-sided cases are frequently associated with extra-digestive anomalies. ${ }^{10}$

The differential diagnosis of gastroschisis should include omphalocele, ruptured omphalocele, hernia of chord and limb-body wall complex. Unlike omphalocele, gastroschisis is not associated with chromosomal abnormalities. If additional abnormalities are detected sonographically, karyotype analyzing should be recommended. ${ }^{6}$

It is well known that fetuses with gastroschisis are at increased risk of intrauterine fetal death at third trimester, fetal growth retardation and preterm labour. ${ }^{6,11}$
There is currently no consensus as to the optimal timing of delivery, nor is there particularly strong evidence to support early elective delivery. It has not been demonstrated neonatal benefit from elective delivery before 38 weeks of gestation. The timing of delivery should be discussed with parents whose fetuses are diagnosed with gastroschisis. ${ }^{12}$ The optimal mode of delivery for fetuses with gastroschisis is also controversial. ${ }^{13}$

Gastroschisis is associated with additional bowel malformations that may lead to considerable morbidity. It is subdivided as simple if isolated or complex if with any coexisting intestinal anomalies at birth such as intestinal atresia, stenosis, perforation, necrosis or volvulus. ${ }^{14}$

Although the survival prognosis for newborns with gastroschisis is good, the rates of intrauterine fetal death and morbidity due to gastrointestinal complications are quite high. Prognoses for infants with gastroschisis are determined primarily by the condition and length of the gut at birth, which are difficult to assess antenatally.

The presence of thickened bowel wall ( $>3$ $\mathrm{mm})$, and intra- or extra abdominal bowel dilatation (intra-lumen diameter from inner wall to inner wall $>6 \mathrm{~mm}$ ) on prenatal ultrasound has been suggested as a predictor of poor postnatal outcome. ${ }^{15-18}$

In our case, although we did not find any extra-intestinal anomalies, the fetal health course was troublesome, and we do not know if it was due to the associated intestinal atresia or the localization of the defect.

Defining and reporting these extraordinary cases is essential to further expand our understanding of these pathologies and their potential associations. 


\section{REFERENCES}

1. Barisic I, Clementi M, Häusler M, Gjergja R, Kern J, Stoll C; Euroscan Study Group. Evaluation of prenatal ultrasound diagnosis of fetal abdominal wall defects by 19 European registries. Ultrasound Obstet Gynecol 2001;18(4):309-16.

2. Ledbetter DJ. Gastroschisis and omphalocele. Surg Clin North Am 2006;86(2):249-60, vii.

3. Curry JI, McKinney $P$, Thornton JG, Stringer MD. The aetiology of gastroschisis. BJOG 2000;107(11):1339-46.

4. Shi Y, Farinelli CK, Chang MS, Carpenter PM. Left-sided gastroschisis with placenta findings: case report and literature review. Int J Clin Exp Pathol 2012;5(3):243-6.

5. Patel RV, More B, Sinha CK, Rajimawale A. Inferior gastroschisis. BMJ Case Rep $2013 \mathrm{Jul}$ 31:2013. doi: 10.1136/bcr-2013-200416.

6. Christison-Lagay ER, Kelleher CM, Langer JC. Neonatal abdominal wall defects. Semin Fetal Neonatal Med 2011;16(3):164-72.

7. Bargy F, Beaudoin S. Comprehensive developmental mechanisms in gastroschisis. Fetal Diagn Ther 2014;36(3):223-30.
8. deVries PA. The pathogenesis of gastroschisis and omphalocele. J Pediatr Surg 1980;15(3):245-51.

9. Hoyme HE, Higginbottom MC, Jones KL. The vascular pathogenesis of gastroschisis: intrauterine interruption of the omphalomesenteric artery. J Pediatr 1981;98(2):228-31.

10. Suver D, Lee SL, Shekherdimian S, Kim SS. Left-sided gastroschisis: higher incidence of extraintestinal congenital anomalies. Am J Surg 2008;195(5):663-6; discussion 666.

11. South AP, Stutey KM, Meinzen-Derr J. Metaanalysis of the prevalence of intrauterine fetal death in gastroschisis. Am J Obstet Gynecol 2013;209(2):114.e1-13.

12. Baud D, Lausman A, Alfaraj MA, Seaward G, Kingdom J, Windrim R, et al. Expectant management compared with elective delivery at 37 weeks for gastroschisis. Obstet Gynecol 2013;121(5):990-8.

13. Puligandla PS, Janvier A, Flageole $H$, Bouchard S, Laberge JM. Routine cesarean delivery does not improve the outcome of infants with gastroschisis. J Pediatr Surg 2004;39(5):742-5.
14. Arnold MA, Chang DC, Nabaweesi R, Colombani PM, Bathurst MA, Mon KS, et al. Risk stratification of 4344 patients with gastroschisis into simple and complex categories. J Pediatr Surg 2007;42(9):1520-5.

15. Goldstein I, Reece EA, Yarkoni S, Wan M, Green JL, Hobbins JC. Growth of the fetal stomach in normal pregnancies. Obstet Gynecol 1987;70(4):641-4

16. Nick AM, Bruner JP, Moses R, Yang EY, Scott TA. Second-trimester intra-abdominal bowel dilation in fetuses with gastroschisis predicts neonatal bowel atresia. Ultrasound Obstet Gynecol 2006;28(6):821-5

17. Kuleva M, Khen-Dunlop N, Dumez Y, Ville Y, Salomon LJ. Is complex gastroschisis predictable by prenatal ultrasound? BJOG 2012;119(1):102-9.

18. Brown N, Nardi M, Greer RM, Petersen S, Thomas J, Gardener G, et al. Prenatal extraabdominal bowel dilatation is a risk factor for intrapartum fetal compromise for fetuses with gastroschisis. Prenat Diagn 2014 Nov 13. doi: 10.1002/pd.4535 